\title{
Updates on Simulation in Obstetrical Anesthesiology Through the COVID-19 Pandemic
}

\author{
Bryan Mahoney, MD*, Elizabeth Luebbert, Do
}

\section{KEYWORDS}

- Obstetrical anesthesiology $\bullet$ High-fidelity simulation $\bullet$ Multidisciplinary team training

- Partial task trainers • Quality improvement • Competency assessment

\section{KEY POINTS}

- Simulation remains essential in the training and assessment of individuals and multidisciplinary teams in obstetric anesthesiology.

- Simulation plays an increasing role in evaluation of work environments, processes, and tools for patient care.

- The challenges presented to caring for obstetric patients during the COVID-19 pandemic revealed the utility of simulation in both training and workflow development.

\section{INTRODUCTION}

Simulation has played a critical role in medicine for decades as a pedagogical or assessment tool utilized at the levels of the individual, multidisciplinary team, and institution. The labor and delivery unit provides an ideal setting for leveraging the advantages provided by simulation given the variety of technical and clinical skills required by health care providers, the collaborative nature of patient care, the potential for unanticipated patient emergencies, and the consistent emphasis on quality improvement in patient care. A useful conceptual model for a survey of simulation in the field of obstetric anesthesiology discriminates the domains of training and assessment along an expanding continuum of learner cohorts: the individual, the patient care team, and the health care organization or environment. Prior reviews of this topic consistently have utilized this approach in surveying the literature on this topic. ${ }^{1-6}$ Given rapid advances in simulation technology and education, an update of simulation in obstetric anesthesiology is in order every few years. Simulation as a tool for training and assessment, however, has proved its utility during the COVID-19 pandemic as training programs and health care systems have been forced to navigate a radically altered learning and patient care environment requiring novel approaches to training and

\footnotetext{
Department of Anesthesiology, Perioperative and Pain Medicine, Mount Sinai Morningside and West Hospitals, 1000 10th Avenue, New York, NY 10019, USA

* Corresponding author.

E-mail address: bryan.mahoney@mountsinai.org
} 
team-based care. This review continues in the tradition of surveying the newest literature on simulation training and assessment for individuals, teams, and systems while also providing a specific overview of the role of simulation in obstetric anesthesiology in the context of the COVID-19 pandemic and the shift toward the virtual learning environment accelerated by social distancing requirements during the pandemic.

\section{SIMULATION-BASED INDIVIDUAL TRAINING AND ASSESSMENT}

The practice of obstetric anesthesiology requires the acquisition of both technical skills and complex nontechnical clinical skills that extend beyond those to which anesthesiology trainees are exposed in the general practice of anesthesiology. Simulation technology can serve as a strategy for this skill acquisition. Partial task trainers (used to address a specific psychomotor or technical skill) and high-fidelity mannequinbased or virtual reality-based simulation (used to address clinical scenarios requiring complex multidomain skill acquisition) are both well described in the obstetric anesthesia simulation literature.

A variety of partial task trainers for spinal or epidural neuraxial technique training have been described and made available to educators. These have ranged from a simulator constructed from a balloon, intubation pillow, and slice of bread, ${ }^{7}$ to anatomically accurate manikin-based or computer-driven or haptic feedback-driven models allowing for trainee practice. ${ }^{8}$ A 2013 review comparing 17 manikin-based simulators to 14 computer-based models by Vaughan and colleagues ${ }^{8}$ notes that although manikin-based simulators are inexpensive, portable, and maintain a higher fidelity as a physical simulation of patient anatomy, computer-based models utilizing haptics provide real-time 3-dimensional screen-based visual feedback combined with a higher fidelity in the loss of resistance technique and better simulating tactile feel of encountering the ligaments, tissues, and bone involved in neuraxial technique. The ideal partial task trainer for neuraxial technique training would combine the physical and anatomic fidelity of manikins with the visuospatial feedback advantages and tactile fidelity found in computer-based models. More recently, haptics have been incorporated with virtual reality and gamification features ${ }^{9,10}$ in an effort to enhance skill acquisition and trainee motivation. The use of a virtual environment now can achieve a higher degree of fidelity in recreating the clinical environment while retaining the fidelity in the tactile sensation of spinal or loss of resistance technique that haptics can provide. Gamification (scoring points and achieving increasing experience levels) increasingly is incorporated into both partial task simulation training and more complex multidomain clinical skills acquisition. ${ }^{11}$ Capogna and colleagues ${ }^{12}$ asked novice trainees engaged in simulated epidural technique training to wear eye-tracking glasses. Although epidural procedure duration and number of attempts decreased following a simulation-based training tutorial, they also found a positive correlation between the number of needle-insertion attempts and gaze fixation counts along with a negative correlation between epidural attempts and gaze duration.

Over the past decade, an increasing volume of research has supported the use of high-fidelity manikin-based simulation for the anesthetic management of the maternal airway and obstetric emergencies. Exposure to high-fidelity simulation in conjunction with traditional lecture-based learning has been shown to enhance trainee performance in emergency management of an obstetric emergency requiring general anesthesia to the competency normally only seen in a fully trained faculty member utilizing a previously validated scoring system with significant retention 8 months following the initial assessment. ${ }^{13,14} \mathrm{~A}$ large volume of scenarios for anesthesia training for obstetric emergencies has been published for educators, including high spinal anesthetic level, ${ }^{15}$ 
maternal cardiac arrest, ${ }^{16}$ and a variety of other conditions. ${ }^{5,17,18}$ Clinton and Minehart provided a roadmap in 2020 for the development of comprehensive simulation curriculum for advancing clinical skills with the inclusion of sample scenarios (Table 1).

Simulation-based training has continued to show effectiveness in learning and retention of skills essential for the practice of obstetric anesthesiology, such as airway management during emergent cesarean delivery, ${ }^{19}$ recognition and management of high neuraxial blockade, ${ }^{20}$ and management of a general anesthetic for cesarean delivery. ${ }^{21}$ The instruction of communication skills increasingly has been addressed through the use of simulation-based training. Raemer and colleagues ${ }^{22}$ explored the role of simulation in overcoming the traditional hierarchical mode of communication within the health care workspace. To promote the ability of residents to speak up on identification of inappropriate clinical behavior on the part of faculty obstetricians, anesthesiologists, and labor and delivery nursing staff, 2 simulated clinical scenarios were provided to allow for the practice of the advocacy-inquiry and 2-challenge inquiry techniques. They found an increase in appropriate challenging behavior from $27 \%$ to $67 \%$ following post-simulation exposure. ${ }^{22}$ More recently, Szmulewicz and colleagues $^{23}$ utilized interdisciplinary simulation-based training for the disclosure of a medical error to patients. This work showed trainees' improvement in both verbal and nonverbal communication skills with retention up to 6 months following the intervention. ${ }^{23}$

\begin{tabular}{|c|c|c|c|}
\hline Characters & Narrative & Vital signs & \\
\hline $\begin{array}{l}\text { High spinal } \\
\text { 1. Patient } \\
\text { (mannequin) } \\
\text { 2. Primary registered } \\
\text { nurse } \\
\text { 3. Primary physician } \\
\text { Time, 0:00-2:00 min } \\
\end{array}$ & $\begin{array}{l}\text { 32-year-old healthy } \\
\text { G2PI } \\
\text { at } 39 \text { wk in labor, } \\
\text { status post recent } \\
\text { epidural placement }\end{array}$ & $\begin{array}{l}\text { Blood pressure, } 110 / 60 \\
\text { Heart rate, } 90 \\
\text { Respiratory rate, } 20 \\
\mathrm{Spo}_{2}, 98 \% \text { on room air }\end{array}$ & $\begin{array}{l}\text { [ ] Engage patient. } \\
\text { [ ] Assess for pain or } \\
\text { discomfort. }\end{array}$ \\
\hline $\begin{array}{l}\text { II } \\
\text { Above, }+ \\
\text { Anesthesia } \\
\text { Backup obstetrician } \\
\text { Second registered } \\
\quad \text { nurse } \\
\text { Resource nurse } \\
\text { Time, } 2.00-4.00 \mathrm{~min}\end{array}$ & $\begin{array}{l}\text { Patient begins to } \\
\text { feel anxious and } \\
\text { is having trouble } \\
\text { breathing }\end{array}$ & $\begin{array}{l}\text { Blood pressure, } 100 / \\
60 ; \\
\text { dropping to } \\
\text { blood pressure 60s/ } \\
40 \text { s } \\
\text { over } 2 \text { min } \\
\text { Heart rate, } 110 \text {; drops } \\
\text { to } 45 \text { over } 2 \text { min } \\
\text { Respiratory rate rises } \\
\text { to } 30 \text { over } 2 \text { min } \\
\mathrm{SpO}_{2}, 98 \%-88 \% \\
\text { Fetal late } \\
\text { decelerations }\end{array}$ & $\begin{array}{l}\text { [ ] Patient distress } \\
\text { [ ] Call for help/ } \\
\text { backup. } \\
\text { [ ] Verbalize } \\
\text { hypotension, } \\
\text { hypoxemia. } \\
\text { [ ] Communicate } \\
\text { critical event. } \\
\text { [ ] Emergency manual } \\
\text { [ ] Examination and } \\
\text { vital signs } \\
\text { verbalization to } \\
\text { group } \\
\text { [ ] Shut off epidural } \\
\text { pump. } \\
\text { [ ] Initiate treatment } \\
\text { of hypotension, } \\
\text { hypoxemia. }\end{array}$ \\
\hline & & & ontinued on next page) \\
\hline
\end{tabular}




\begin{tabular}{|c|c|c|c|}
\hline $\begin{array}{l}\text { Table } 1 \\
\text { (continued) }\end{array}$ & & & \\
\hline Characters & Narrative & Vital signs & \\
\hline $\begin{array}{l}\text { III } \\
\text { Above, }+ \\
\text { Additional registered } \\
\quad \text { nurse support } \\
\text { Second anesthesia } \\
\text { Second obstetric } \\
\text { provider } \\
\text { Any available } \\
\text { additional help } \\
\text { Time, 4:00-8:00 }\end{array}$ & $\begin{array}{l}\text { Patient unresponsive, } \\
\text { unconscious } \\
\text { Event pause and } \\
\text { discuss situation } \\
\text { (mini-debrief) to } \\
\text { ensure proper } \\
\text { treatment } \\
\text { (optional) }\end{array}$ & $\begin{array}{l}\text { Blood pressure, } 55 / 30 \\
\text { Heart rate } 45 ; \text { drops } \\
\text { to } 30 \text { if not treated } \\
\text { Respiratory rate falls } \\
\text { to } 0 \text { when systolic } \\
\text { blood pressure } \\
\text { drops } \\
\text { below } 60 \\
\mathrm{Spo}_{2}, 88 \% \text {; falls } \\
\text { rapidly } \\
\text { to } 40 \% \text { if not bag- } \\
\text { mask } \\
\text { ventilated and } \\
\text { then intubated } \\
\text { Fetal heart rate, } \\
\text { prolonged } \\
\text { deceleration }\end{array}$ & $\begin{array}{l}\text { [ ] Support } \\
\text { hypotension/ } \\
\text { anaphylaxis kit } \\
\text { [ ] Ambu bag and } \\
\text { ventilate } \\
\text { [ ] Ventilation support/ } \\
\text { hypotension } \\
\text { management with } \\
\text { epinephrine } \\
\text { infusion or other } \\
\text { appropriate } \\
\text { available } \alpha \text {-/ } \\
\beta \text {-agonists } \\
\text { [ ] Communicate } \\
\text { patient is } \\
\text { unconscious (to } \\
\text { team). } \\
\text { [ ] Verbalize fetal } \\
\text { intolerance of } \\
\text { hypotension. } \\
\text { [ ] Establish event } \\
\text { manager. } \\
\text { [ ] Communicate } \\
\text { possible causes of } \\
\text { loss of } \\
\text { consciousness and } \\
\text { initiate plan for } \\
\text { immediate care. } \\
\text { [ ] Code cart, } \\
\text { defibrillator } \\
\text { [ ] Emergency manual }\end{array}$ \\
\hline $\begin{array}{l}\text { IV } \\
\text { All team members } \\
\text { Time, } 8.00-10.00\end{array}$ & Recovery with support & $\begin{array}{l}\text { Blood pressure, 90/60 } \\
\text { Heart rate, } 70 \\
\text { Fetal recovery with } \\
\text { restitution of } \\
\text { maternal vital signs }\end{array}$ & $\begin{array}{l}\text { End scenario with } \\
\text { resuscitation and } \\
\text { plan for supportive/ } \\
\text { intensive care while } \\
\text { spinal regresses }\end{array}$ \\
\hline
\end{tabular}

Advances in both Web-based and communication technologies increasingly have been integrated into simulation education for trainees, removing the need for both trainee and instructor to be in the same location. Telesimulation has become a tool to provide training of technical and nontechnical skills around the world. The use of telesimulation was described by educators in Canada to teach trainees in Botswana laparoscopic surgical technique with nothing more than a simple trainer box, a Web camera, and a laptop computer. ${ }^{24}$ A randomized trial conducted by Sorenson and colleagues $^{25}$ in 2017 compared simulation-based obstetric anesthesia training in clinical management of an emergency caesarean section and a postpartum hemorrhage (PPH) scenario with in situ simulation versus off-site simulation. They found similar individual and team outcomes in patient safety attitudes, stress, motivation, perceptions of the simulations, and team performance while those receiving in situ simulation training did find a greater degree of fidelity than those receiving remote training. Given the success found in telesimulation-based training in both technical and nontechnical 
clinical skills acquisition, remote teaching may be an exciting frontier for the teaching of neuraxial technique or anesthetic management of obstetric emergencies by international experts to trainees around the world. Recent work by Lim and colleagues, ${ }^{26}$ showing that mental imagery training can be used to develop epidural anesthesia technical skills as effectively as low-fidelity haptic simulators, even may suggest that effective remote education could be provided with only a Web camera.

Simulation-based skills assessment has continued in line with advances in training. Kiwalabye and colleagues ${ }^{27}$ assessed preparedness of anesthesia interns in managing a failed obstetric intubation following their anesthesiology rotation. They observed a pass rate of only $40 \%$ despite prior exposure to an Essential Steps in Managing Obstetric Emergencies training module, leading them to propose that this gap in skill acquisition discovered by simulated scenarios can be remedied through the use of simulation-based education during their training. An additional area in which simulation increasingly has been used in assessment lies in credentialing of those who have graduated from anesthesiology training programs. Since 2018, the American Board of Anesthesiology has included Objective Structured Clinical Examinations (OSCEs) as part of the APPLIED examination, including simulated interactions with patients. Although the technical and clinical components of obstetric anesthesia practice currently are not among the topics included in the OSCEs, communication with the parturient is addressed in modules assessing informed consent and communication of medical errors. This has led many programs to integrate OSCE training into their residency curriculum to better prepare trainees for the process of credentialing. Dabbagh and colleagues ${ }^{28}$ found an increase in the relative annual pass rate of anesthesiology residents following the integration of a preparation program, including mock OSCEs prior to the National Board of Anesthesiology certifying examination.

\section{SIMULATION-BASED MULTIDISCIPLINARY TEAM TRAINING AND ASSESSMENT}

Multidisciplinary team training for obstetric care and crisis resource management (CRM) has been well described in the simulation literature. ${ }^{29}$ Although confidence in this approach as a means to improve patient outcomes has been shown by stakeholders, such as insurance companies, there has long been effort to link the utilization of simulation for team training to improvements in patient outcomes. ${ }^{30}$ A recent review of simulation team training, including human factors components, has provided some insight into this long-standing goal of those engaged in the field. Five single prospective site studies investigating multidisciplinary obstetric simulation training, including CRM and reported outcomes in high-resource and low-resource countries, were identified. ${ }^{31}$ Two showed a $34 \%$ reduction in maternal mortality and 3 a $41 \%$ to $50 \%$ reduction in blood transfusion, whereas cluster analysis revealed a $17 \%$ reduction in $\mathrm{PPH}$ incidence and a $37 \%$ reduction on weighted obstetrics adverse outcomes. Furthermore, there was a $15 \%$ reduction in maternal mortality in favor of trained teams and a reduction of neonatal deaths from 24 weeks during the first 24 hours of $83 \%$ in intervention sites compared with an $18 \%$ increase in control sites. Lutgendorf and colleagues ${ }^{32}$ conducted 16 multidisciplinary simulated scenarios, including PPH over 2 days to assess team performance and operational readiness. A comparison of PPH incidents in their institution revealed a decrease in the time to prepare blood products over the course of simulation training and a trend toward a reduction in the incidence of $\mathrm{PPH} .{ }^{32}$ These important results only increase the need for further work exploring the impact of simulation-based team training on obstetric patient and neonatal outcomes.

Although work continues in the field of developing simulation-based team training curricula, ${ }^{33}$ several studies have investigated team behavior through the use of 
simulation. A recent prospective observational study utilized individual personality testing to find associations with overall assessments of teamwork and communication in simulated management of PPH. The investigators discovered that a high degree of neuroticism among individual team members led to increased communication in a manner that was detrimental to overall team performance whereas other personality traits yielded no associations. ${ }^{34}$ Capogna and colleagues ${ }^{35}$ had team leaders of a simulated PPH scenario wear eye-tracking glasses to find associations between eye-tracking metrics of 27 selected areas of interest and team performance evaluated by a PPH checklist. Their group found that high-performance leader groups were associated with a greater duration of visual fixations as well as a more uniform distribution of gaze on team members compared with the low-performance leader groups. Methods of evaluating teams during obstetric emergencies, such as $\mathrm{PPH}$, continue to evolve as more evidence is brought to bear on the importance of nontechnical skills, such as cognitive and social factors. Toward this end, Cheloufi and colleagues ${ }^{36}$ employed a multidisciplinary Delphi method consisting of 4 cycles with 16 experts, including obstetricians, midwives, and anesthesiologists to create the Obstetric Team Performance Assessment Scale to be utilized during assessment of team performance during high-fidelity simulation exercises. This scale, based on expert consensus, emphasized the value of nontechnical skills, such as situational awareness and requesting help from the anesthesia team, in addition to traditionally identified checklist items, such as intravenous access and prompt activation of transfusion protocols. This work reflects the increased emphasis on the psychometric and social factors in the role of team performance being better understood through simulation.

\section{SIMULATION-BASED ASSESSMENT OF THE WORK ENVIRONMENT AND PRACTICE METHODS}

Hemorrhage remains a leading cause of death in parturients and an area of interest in developing protocols for quantification and management of blood loss. Simulation has been used effectively to assess the accuracy of different methods of blood loss quantification. The use of a pictorial guide as a means to assess blood loss during a simulated cesarean delivery was evaluated by Homcha and colleagues ${ }^{37}$ comparing assessments of blood loss prior to and after use of the guide. Prior to use of the pictorial guide, they observed a more than $25 \%$ overestimation of blood loss, whereas use of the guide revealed an increase from $7 \%$ to $24 \%$ of accurate estimation defined as an estimate within $5 \%$ of the actual volume lost. Piekarski and colleagues ${ }^{38}$ sought to compare a mobile colorimetric application for blood loss estimation with visual and gravimetric methods utilized by 53 anesthesiologists exposed to a simulated PPH scenario. They found the least deviation in estimates from the actual volume of blood loss among the colorimetric estimation followed by gravimetric and visual methods, whereas overestimation of blood loss occurred most in the visual estimation followed by the gravimetric and colorimetric methods.

The risk of chlorhexidine contamination of materials introduced to the neuraxial space motivated Taylor and colleagues ${ }^{39}$ to conduct a simulated study to identify the incidence of transfer of chlorhexidine from the lumbar region to standard surgical gloves in a study simulating standard lumbar region antiseptic preparation. Their findings revealed an incidence of primary transfer above $99 \%$ up to 10 minutes following chlorhexidine application to the lumbar region of volunteers, with a $68.9 \%$ incidence of secondary transfer from gloves to another surface. To evaluate the effectiveness of current Society for Obstetric Anesthesia and Perinatology (SOAP) Patient Safety Committee proposals to utilize a cap and run approach (capping epidural and intravenous 
lines to prevent tangling prior to transfer) to facilitate transport of patients from the labor room to operating theater during emergency cesarean deliveries. Mhyre and colleagues ${ }^{40}$ utilized a prospective randomized in situ simulation study. They found no statistically significant difference in the time from decision to proceed with cesarean delivery to readiness for general anesthesia between groups, although qualitative analysis during debriefing did reveal some perceived advantages, such as bed maneuverability and a decrease in tangled lines.

Efforts in low-income and middle-income nations to decrease maternal mortality hold great promise, given the ongoing discrepancy with rates observed in high-income nations. Simulation continues to play a large role in both education and developing or assessing initiatives aimed at improving maternal care. Alexander and colleagues ${ }^{41}$ used the simulated setting to pilot test a context-relevant safe anesthesia checklist for cesarean delivery in East Africa. By comparing anesthesiologists providing care for a variety of conditions in the simulated environment with and without a checklist developed in conjunction with East African health care professionals, they found a significant increase in the completion of critical actions in the setting of preeclampsia and PPH. Gallardo and colleagues ${ }^{42}$ utilized the simulated environment and a randomized crossover design, including 10 trainees, to compare the performance of trainees in simulated high-resource and low-resource environments managing $\mathrm{PPH}$ from uterine atony. They found a significant decrease in performance by those exposed to the simulated low-resource environment, including both technical and nontechnical skills, including leadership, resource utilization, and communication.

\section{SIMULATION IN OBSTETRIC ANESTHESIOLOGY DURING THE COVID-19 PANDEMIC}

The COVID-19 pandemic has radically altered the landscape for clinicians and educators across the world, and the invaluable role of simulation came to the fore in the field of obstetric anesthesiology. With direct patient contact and in-person teaching limited by social distancing requirements and infectious risk mitigation, simulation provided opportunities for medical students and anesthesiology trainees to learn both technical and nontechnical clinical skills. To accelerate education for management of critical events in the context of patients infected with COVID-19, high-fidelity simulationbased individual and team training proved invaluable. Most importantly, with the need to develop new work environments and processes, simulation technology served to test their feasibility and prepare health care systems and medical staff.

Trainees found their ability to attain obstetric anesthesiology skills and knowledge limited by the fact that patient care brought a level infectious risk not previously common to the labor and delivery unit. In-person teaching also was impacted by requirements for social distancing imposed on training programs. Although the surgical volume elsewhere in hospitals decreased profoundly by the cancellation or delay of all but the most urgent surgical procedures, such measures could not be taken in labor and delivery units, and the need for clinical care remained relatively unaffected. Training programs leveraged simulation technology, such as partial task trainers, to provide exposure to neuraxial technique given the need for personal protective equipment (PPE) during patient interactions and limited exposure to parturients with known or suspected COVID$19 .{ }^{43}$ Simulation also was described as a mechanism for training difficult airway management, PPE protocols, aseptic technique, and airway management. Virtual reality with gamification features also was described as a tool for approaching the maternal airway.

Previously routine interactions with patients changed dramatically during the pandemic, necessitating rapid training of health care providers to mitigate the risk of infection to providers and patients. Professional societies turned to in situ 
multidisciplinary simulation as a resource for physicians and other health care professionals early in the pandemic. The American College of Obstetricians and Gynecologists Simulations Working Group created 4 standardized scenarios for use to guide multidisciplinary teams in patient interactions during the pandemic: (1) an obstetric patient with suspected COVID-19 presenting in labor; (2) an obstetric patient with suspected COVID-19 progressing in labor to spontaneous vaginal delivery, (3) an

\section{COVID19 LABOR TO CESAREAN DELIVERY: CASE FLOW AND FACILITATOR'S GUIDE}

Author: Rebecca D. Minehart, MD, MSHPEd

Contributors: Gill Abir, MD; Katie Arendt, MD; Erik Clinton, MD; Roxane Gardner, MD, MSHPEd, DSc; Daniel Katz, MD; Allison Lee, MD; Vanessa Torbenson, MD

Notes to facilitators:

- Please feel free to drill any relevant part(s) of this and omit those parts that are not relevant.

- Please modify anything that does not align with your institutional guidelines.

- Consider holding small sessions ( $\leq 6$ people) and/or hosting virtual sessions using filmed footage to talk through considerations with a larger team

- Consider prioritizing PPE when holding drills for the first time, and adding in additional components later (such as the support person, etc.)

- Please note that the focus of this packet of drills is not to be physiologically representative of any particular clinical situation; rather, it is meant as a platform to practice teamwork and organizational skills

\section{SCENARIO Synopsis to orient participants:}

- Cori Vidman is a 30 yo G2P1 female at 37w2d who presents to triage in active labor after ROM.

- Her PMH includes asthma, h/o rapid first labor, and recent onset of cold-like symptoms. No known COVID19 exposures.

- She is requesting labor analgesia but has not been seen by an obstetrics/midwife provider yet (if starting in triage).

- She needs evaluation, assessment, and treatment.

\section{Equipment needed:}

- Mannequin or standardized patient/actor (for mother); (optional: standardized patient/actor for support person for Part 4)

- Neonatal mannequin/trainer (if doing neonatal scenario)

- Space for using as triage bed, labor room, OR as needed

- Plan for PPE-consider using props (e.g., handkerchiefs or facial tissues/Kleenex taped to ears for masks, patient robes worn backwards for gowns, likely can use gloves as these are not generally on shortage-otherwise, consider miming all donning/doffing or using lanyards to denote PPE items)

- Appropriate monitors for settings, appropriate equipment for OR (can mime for surgical equipment, but will likely need anesthetic equipment if possible, and airway equipment if performing intubation/extubation)

\section{OVERALL FLOW}

\begin{tabular}{|c|c|c|c|}
\hline Time & & Key Scenario Points & Ideal Actions \\
\hline Pre-drill & $\begin{array}{l}\text { Orient } \\
\text { Participants to } \\
\text { patient in triage } \\
\text { area }\end{array}$ & $\begin{array}{l}\text { - Patient is in triage bed (mannequin vs } \\
\text { standardized patient/actor) }\end{array}$ & $\begin{array}{l}\text { - Orient team members to drill environment } \\
\text { - Discuss use of props/miming to conserve } \\
\text { PPE and other equipment }\end{array}$ \\
\hline $\begin{array}{l}\text { Part 1: } \\
\text { Triage eval }\end{array}$ & $\begin{array}{l}\text { Patient in } \\
\text { active labor } \\
\text { Participants } \\
\text { involved (as } \\
\text { per institution): } \\
\text { OB/CNM, RN, } \\
\text { anesthesia } \\
\text { provider to } \\
\text { assess } \\
\text { respiratory } \\
\text { status }\end{array}$ & $\begin{array}{l}\text { - Patient coughing, in active labor } \\
\text { - (Patient may have mask on if available } \\
\text { through regular entry points) } \\
\text { Maternal baseline vitals: } \\
\text { BP: } 120 / 50 \\
\text { HR: } 112 \\
\text { O2 Sat: } 92 \% \text { on RA (goes to } 95 \% \text { on any } \\
\text { O2) } \\
\text { RR: } 21 \\
\text { Temp: } 99.9 F \text {; FHR: Category I tracing } \\
\text { - Relevant history: symptoms started a } \\
\text { week ago; her toddler had a playdate } \\
\text { around that time and maybe the other }\end{array}$ & $\begin{aligned} \text { Clinical: } \\
\text { 1. } \\
\text { Correct donning of PPE outside of } \\
\text { triage room according to institutional } \\
\text { guidelines ( }{ }^{* *} \text { consider practicing } \\
\text { with props or having people mime } \\
\text { steps rather than using actual PPE**) } \\
2 . \quad \text { (Correct contactless passing of mask } \\
\text { to patient if she has no mask on; } \\
\text { again, consider practicing with props } \\
\text { or miming) } \\
\text { 3. Confirm patient identity and perform } \\
\text { focused history and physical exam } \\
\text { (may discuss airway exam depending }\end{aligned}$ \\
\hline
\end{tabular}

Fig. 1. Covid 19 labor to cesarean delivery: case flow and facilitator's guide. BP: blood pressure, BPH: Beats per minute, CNM: Certified Nurse Midwives, C/D: cesarean delivery, Cm: centimeters, ETT: Endotracheal tube, EtCO2: End tidal carbon dioxide, EBL: Estimated blood loss, F: Fahrenheit, FHR: Fetal Heart Rate, GA: General Anesthesia, HR: Heart rate, NICU: Neonatal intensive care unit, NMB: Neuromuscular blocking agents, OB: obstetrician, $\mathrm{O} 2$ sat: Oxygen saturation, OR: operating room, O2: oxygen, PAPR: Powered Air Purifying Respirators, PPE, personal protective equipment; MP: Mallampati, RN: registered nurse, RR: Respiratory Rate, RSV: Respiratory syncytial virus, RA: Room air, TOF: Train of four. 


\begin{tabular}{|c|c|c|c|}
\hline & & $\begin{array}{l}\text { family has some people with colds. } \\
\text { Otherwise, she feels her asthma is } \\
\text { exacerbated recently, and thinks it may } \\
\text { be due to allergies. } \\
\text { - Relevant physical exam: cervical exam } \\
\text { is } 6 \mathrm{~cm} / 90 \% /-1 \text { station (hand paper } \\
\text { with written exam to OB/CNM). Airway } \\
\text { exam (if done-this may be a point of } \\
\text { discussion) shows MP 3, otherwise } \\
\text { favorable airway features. Lung exam } \\
\text { demonstrates diminished sounds at } \\
\text { right base. Other findings normal. } \\
\text { During contractions, once surgical or } \\
\text { oxygen mask is placed, patient may } \\
\text { occasionally remove surgical/oxygen } \\
\text { mask but will respond to replace mask } \\
\text { if asked by staff } \\
\text { PAUSE AND DISCUSS AT ANY POINT } \\
\text { DURING CASE TO HIGHLIGHT GOOD } \\
\text { BEHAVIORS OR HAVE PARTICIPANTS } \\
\text { REDO }\end{array}$ & $\begin{array}{l}\text { on institutional guidelines) } \\
\text { 4. Apply oxygen to patient } \\
\text { 5. Obtain influenza, RSV, coronavirus } \\
\text { swabs } \\
\text { Behavioral: } \\
\text { 1. Clear communication between staff } \\
\text { members to coordinate entry into } \\
\text { triage room } \\
\text { 2. Clear role delineation and plan to } \\
\text { move patient to labor room } \\
\text { 3. Updates to labor room to coordinate } \\
\text { receiving patient } \\
\text { 4. Encourage patient to keep mask on } \\
\text { (perhaps even designate someone to } \\
\text { watch this to limit spread) } \\
\text { 5. Clear communication to others at an } \\
\text { institutional level that a patient with } \\
\text { possible CoviD19 is present (per } \\
\text { institutional policies) } \\
\text { (Optional: Team can } \\
\text { Name/Claim/Aim to orient } \\
\text { participants to situation and organize } \\
\text { their team's activities) }\end{array}$ \\
\hline $\begin{array}{l}\text { Part 2: } \\
\text { Triage to } \\
\text { labor room }\end{array}$ & $\begin{array}{l}\text { Patient } \\
\text { needing } \\
\text { transport } \\
\text { Participants (as } \\
\text { per institution): } \\
\text { [insert } \\
\text { appropriate } \\
\text { participants] }\end{array}$ & $\begin{array}{l}\text { - Patient being transported to labor room, } \\
\text { needs to be counseled to keep mask on } \\
\text { (surgical or oxygen mask, depending on } \\
\text { what has been placed-can be discussed } \\
\text { that oxygen mask may not protect } \\
\text { others) } \\
\text { - (Optional: Patient's support person } \\
\text { arrives on labor floor, is a close contact } \\
\text { of patient) } \\
\text { Maternal vitals in labor room: } \\
\text { BP: } 131 / 72 \\
\text { HR: } 125 \\
\text { O2 Sat: } 92 \% \text { on RA (goes to } 95 \% \text { on any } \\
\text { O2) } \\
\text { RR: } 21 \\
\text { Temp: } 99.9 F ; \text { FHR: Category } 2 \text { tracing } \\
\text { - Patient still contracting, will remove } \\
\text { mask if not counseled } \\
\text { - Patient arrives in labor room, requests } \\
\text { anesthesia provider for neuraxial } \\
\text { placement } \\
\text { - Cervical exam on entry to room is } \\
7 \mathrm{~cm} / 100 \% / 0 \text { station } \\
\text { PAUSE AND DISCUSS AT ANY POINT } \\
\text { DURING CASE TO HIGHLIGHT GOOD } \\
\text { BEHAVIORS OR HAVE PARTICIPANTS } \\
\text { REDO }\end{array}$ & 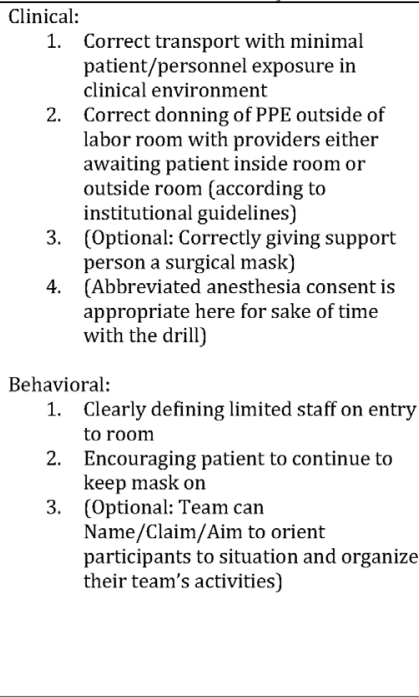 \\
\hline $\begin{array}{l}\text { Part 3: Fetal } \\
\text { brady, } \\
\text { transfer to } \\
\text { OR }\end{array}$ & $\begin{array}{l}\text { Patient with } \\
\text { recent } \\
\text { neuraxial } \\
\text { analgesia, } \\
\text { getting } \\
\text { comfortable, } \\
\text { with } \\
\text { nonreassuring } \\
\text { fetal status }\end{array}$ & $\begin{array}{l}\text { - Patient now getting comfortable after } \\
\text { neuraxial placement, still with some } \\
\text { discomfort (low suprapubic) } 5 \text { minutes } \\
\text { after anesthetic initiation } \\
\text { - FHR then drops to } 80 \text { BPM with } \\
\text { recurrent late decelerations (Category } \\
3 \text { tracing) without uterine } \\
\text { hyperstimulation }\end{array}$ & $\begin{array}{ll}\text { Clinical: } \\
\text { 1. } \\
\text { Early dosing of neuraxial for C/D to } \\
\text { avoid need for intubation } \\
\text { 2. } \begin{array}{l}\text { Correct donning of PPE for all } \\
\text { providers necessary for care }\end{array} \\
\text { 3. } \begin{array}{l}\text { Correct transport and personnel } \\
\text { involved in moving patient into the } \\
\text { OR while minimizing exposure of } \\
\text { others }\end{array}\end{array}$ \\
\hline
\end{tabular}

Fig. 1. (continued). 


\begin{tabular}{|c|c|c|c|}
\hline & $\begin{array}{l}\text { Participants (as } \\
\text { per institution): } \\
\text { [insert } \\
\text { appropriate } \\
\text { participants] }\end{array}$ & $\begin{array}{l}\text { Maternal vitals at this time: } \\
\text { BP: } 108 / 50 \\
\text { HR: } 126 \\
\text { O2 Sat: } 92 \% \text { on RA (goes to } 95 \% \text { on any } \\
\text { O2) } \\
\text { RR: } 21 \\
\text { Temp: } 99.9 \mathrm{~F} ; \text { FHR Category } 2 \rightarrow 3 \\
\text { - Cervical exam is } 8 \mathrm{~cm} / 100 \% / 0 \text { station } \\
\\
\text { PAUSE AND DISCUSS AT ANY POINT } \\
\text { DURING CASE TO HIGHLIGHT GOOD } \\
\text { BEHAVIORS OR HAVE PARTICIPANTS } \\
\text { REDO }\end{array}$ & $\begin{array}{l}\text { 4. Consider the role of preparing to use } \\
\text { N95/PAPR for the entire team in case } \\
\text { of general anesthesia/intubation } \\
\text { Behavioral: } \\
\text { 1. Clear communication to teams to } \\
\text { ready equipment in the OR } \\
\text { 2. Clear role delineation when organize } \\
\text { to move patient } \\
\text { 3. (Optional: Team can } \\
\text { Name/Claim/Aim to orient } \\
\text { participants to situation and organize } \\
\text { their team's activities) }\end{array}$ \\
\hline $\begin{array}{l}\text { Part 4: } \\
\text { STAT C/D } \\
\text { and } \\
\text { conversion } \\
\text { to GA with } \\
\text { intubation }\end{array}$ & $\begin{array}{l}\text { Patient with } \\
\text { inadequate } \\
\text { level of } \\
\text { anesthesia, } \\
\text { needing to } \\
\text { convert to GA } \\
\text { with } \\
\text { intubation } \\
\text { Participants (as } \\
\text { per institution): } \\
\text { [insert } \\
\text { appropriate } \\
\text { participants] }\end{array}$ & $\begin{array}{l}\text { - Patient in OR, fails level (level at T10 } \\
\text { bilaterally) *or* patient with adequate } \\
\text { level but complains of pain with } \\
\text { incision } \\
\text { Maternal vitals at this time: } \\
\text { BP: } 108 / 50 \\
\text { HR: } 126 \text { (goes to } 100 \text { with any } \\
\text { phenylephrine) } \\
\text { O2 Sat: } 92 \% \text { on RA (goes to } 95 \% \text { on any } \\
\text { O2 } \rightarrow \text { can go to } 99 \% \text { on } 100 \% \text { o with } \\
\text { preoxygenation, over } 8 \text { breaths) } \\
\text { RR: } 21 \\
\text { Temp: } 99.9 F ; \text { FHR Category } 3 \text { (still } 80 \\
\text { BPM if checked) } \\
\text { - Cervical exam is } 8 \mathrm{~cm} / 100 \% /+1 \text { station } \\
\text { - (Optional, depending on institutional } \\
\text { policies): Patient's support person } \\
\text { needs a plan-whether this person is } \\
\text { already in the OR by now, or whether } \\
\text { this person needs to be updated is up } \\
\text { to the facilitators } \\
\text { PAUSE AND DISCUSS AT ANY POINT } \\
\text { DURING CASE TO HIGHLIGHT GOOD } \\
\text { BEHAVIORS OR HAVE PARTICIPANTS } \\
\text { REDO }\end{array}$ & $\begin{aligned} \text { Clinical: } \\
\text { 1. } \\
\text { porrect PPE of ALL TEAM MEMBERS } \\
\text { institutional guidelines) } \\
\text { 2. Correct equipment ready to prepare } \\
\text { for any difficulty in intubation (e.g., } \\
\text { videolaryngoscopy) } \\
\text { 3. Preoxygenation with lowest O2 flows } \\
\text { possible, and with HEPA filter } \\
\text { 4. } \\
\text { ETT cuff inflated prior to positive } \\
\text { pressure ventilation } \\
\text { Behavioral: } \\
\text { 1. Clear communication around the } \\
\text { time of intubation to coordinate help } \\
\text { and steps } \\
\text { 2. Clear role delineation when initiating } \\
\text { general anesthesia } \\
\text { 3. Clear communication of now- } \\
\text { contaminated areas, with steps to } \\
\text { minimize further contamination of } \\
\text { personnel } \\
\text { 4. (Optional: Description of } \\
\text { conversation with support person, } \\
\text { and clear communication to support } \\
\text { person in labor room, or removal of } \\
\text { support person from OR) } \\
\text { 5. (Optional: Clear communication with } \\
\text { support person of isolation protocols } \\
\text { for neonate, per institutional } \\
\text { guidelines) } \\
\text { 6. Ioptional: Team can } \\
\text { Name/Claim/Aim to orient } \\
\text { participants to situation and organize } \\
\text { their team's activities) }\end{aligned}$ \\
\hline $\begin{array}{l}\text { Part 5: } \\
\text { Neonatal } \\
\text { resuscitation } \\
\text { and } \\
\text { transport }\end{array}$ & $\begin{array}{l}\text { Patient under } \\
\text { general } \\
\text { anesthesia, } \\
\text { neonate } \\
\text { requiring } \\
\text { resuscitation } \\
\text { and transport } \\
\text { to } \\
\text { NICU/isolation } \\
\text { (per } \\
\text { institution) } \\
\text { Participants (as }\end{array}$ & $\begin{array}{l}\text { Patient stable during delivery, under } \\
\text { general anesthesia } \\
\text { Maternal vitals at this time: } \\
\text { BP: } 108 / 50 \\
\text { HR: } 107 \text { (goes to } 100 \text { with any } \\
\text { phenylephrine) } \\
\text { O2 Sat: } 97 \% \text { on } 100 \% 02 \rightarrow 94 \% \text { if nitrous } \\
\text { oxide used } \\
\text { RR: (set by ventilator) -can be } 15 \text {, EtCO2 } \\
\text { is } 28 \\
\text { Temp: } 99.9 F \\
\text { EBL: } 800 \mathrm{~mL} \text {, good uterine tone }\end{array}$ & $\begin{array}{l}\text { Clinical: } \\
\text { 1. Correct PPE of all team members in } \\
\text { OR and caring for neonate } \\
\text { 2. Correct neonatal resuscitation } \\
\text { personnel available in OR } \\
\text { 3. Correct equipment and isolation } \\
\text { procedures demonstrated while } \\
\text { preparing to transport neonate (per } \\
\text { institutional guidelines) } \\
\text { 4. Correct transport out of OR while } \\
\text { minimizing contact with neonate (per } \\
\text { institutional guidelines) }\end{array}$ \\
\hline
\end{tabular}

Fig. 1. (continued). 


\begin{tabular}{|c|c|c|c|}
\hline & $\begin{array}{l}\text { per institution): } \\
\text { [insert } \\
\text { appropriate } \\
\text { participants] }\end{array}$ & $\begin{array}{l}\text { Neonate at delivery: } \\
\text { Color: Blue/dusky color } \\
\text { Heart rate: } 80 \\
\text { Reflex irritability: No response } \\
\text { Muscle tone: Limp } \\
\text { Respiration: Absent } \\
\text { APGARs at } 1 \& 5 \text { minutes (with any } \\
\text { resuscitation): } \\
\text { Color: Acrocyanotic } \\
\text { Heart rate: } 130 \\
\text { Reflex irritability: Grimace } \\
\text { Muscle tone: Some flexion } \\
\text { Respiration: Weak Cry/Hypoventilation } \\
\text { - Neonate needs transportation/isolation } \\
\text { (per institutional guidelines) } \\
\text { PAUSE AND DISCUSS AT ANY POINT } \\
\text { DURING CASE TO HIGHLIGHT GOOD } \\
\text { BEHAVIORS OR HAVE PARTICIPANTS } \\
\text { REDO }\end{array}$ & $\begin{array}{l}\text { Behavioral: } \\
\text { 1. Clear communication within neonatal } \\
\text { team regarding care of neonate } \\
\text { 2. Clear role delineation when caring } \\
\text { for neonate } \\
\text { 3. (Optional: Team can } \\
\text { Name/Claim/Aim to orient } \\
\text { participants to situation and organize } \\
\text { their team's activities) }\end{array}$ \\
\hline $\begin{array}{l}\text { Part 6: } \\
\text { Extubation, } \\
\text { recovery } \\
\text { and } \\
\text { disposition } \\
\text { of patient }\end{array}$ & $\begin{array}{l}\text { Procedure } \\
\text { complete, } \\
\text { patient stable }\end{array}$ & $\begin{array}{l}\text { - Cesarean delivery completed } \\
\text { Maternal vitals at this time: } \\
\text { BP: } 128 / 70 \\
\text { HR: } 125 \\
\text { O2 Sat: } 97 \% \text { on } 100 \% 02 \\
\text { RR: (breathing spontaneously) — can be } \\
21, \text { EtCO2 is } 28 \\
\text { Temp: } 99.9 \mathrm{~F} \\
\text { TOF: } 0.9 \text { (if additional nondepolarizing } \\
\text { NMBs used) } \\
\text { - At start of Part } 6 \text {, all anesthetic agents } \\
\text { are turned off, patient is making some } \\
\text { movements indicative of emergence } \\
\text { (but not following commands yet) } \\
\text { - Patient then emerges normally, needs } \\
\text { extubation (vitals do not change } \\
\text { dramatically after extubation-SpO2 } \\
\text { can drop to } 95 \% \text { on } 100 \% \text { O2 by } \\
\text { oxygen mask) } \\
\text { PAUSE AND DISCUSS AT ANY POINT } \\
\text { DURING CASE TO HIGHLIGHT GOOD } \\
\text { BEHAVIORS OR HAVE PARTICIPANTS } \\
\text { REDO }\end{array}$ & $\begin{aligned} \text { Clinical: } \\
\text { 1. } \\
\text { Minimize personnel who are } \\
\text { 2. Correct PPE use (with N95/PAPR) } \\
\text { 3. Consider decreasing oxygen flows } \\
\text { during extubation or placing } \\
\text { anesthesia machine on standby (per } \\
\text { institutional guidelines) } \\
\text { 4. Correct limiting of spreading } \\
\text { contamination on surfaces related to } \\
\text { anesthesia workstation } \\
\text { 5. Correct moving of patient to } \\
\text { appropriate recovery area (per } \\
\text { institutional guidelines) } \\
\text { Behavioral: } \\
\text { 1. Clear communication and } \\
\text { organization of team during } \\
\text { extubation with warning others to } \\
\text { stay back in case of patient coughing } \\
\text { 2. Anticipating and planning for } \\
\text { gathering all equipment needed for } \\
\text { extubation and sequestering it prior } \\
\text { to extubation } \\
\text { 3. Clear communication of plan in case } \\
\text { of airway obstruction } \\
\text { 4. Clear communication of recovery and } \\
\text { disposition plan with team (per } \\
\text { institutional guidelines) } \\
\text { 5. Optional: Team can } \\
\text { Name/Claim/Aim to orient } \\
\text { participants to situation and organize } \\
\text { their team's activities) }\end{aligned}$ \\
\hline Post-drill & End Case & \multicolumn{2}{|c|}{$\begin{array}{l}\text { Clearly state, "Thank you so much-we are concluding this drill and will now focus on our } \\
\text { debrief of the whole session." }\end{array}$} \\
\hline \multicolumn{4}{|c|}{ COVID19 Debriefing (suggested structure) } \\
\hline $\begin{array}{l}\text { Location: can } \\
\text { be in situ or }\end{array}$ & \multicolumn{3}{|l|}{$\begin{array}{l}\text { DEBRIEF Case: } \\
\text { - Reaction }\end{array}$} \\
\hline
\end{tabular}

Fig. 1. (continued). 


\begin{tabular}{|c|c|}
\hline $\begin{array}{l}\text { in a separate } \\
\text { location }\end{array}$ & $\begin{array}{l}\text { - Move to "Plus/Delta" debrief } \\
\text { "one word" to describe elicited emotion } \\
\text { and underns "Delta" column are things that the team could change or improve } \\
\text { Facilitators should find a few things that the teams did well to highlight to them, as } \\
\text { participants are usually hard on themselves (and under a great deal of stress right now) } \\
\text { Facilitators can also make a culumn of "unanswered/new questions" that need to be } \\
\text { addressed at an institutional level, with a promise to circle back with participants } \\
\text { - Move to "Take-aways" phase } \\
\text { Ask participants what they are taking away from the session today (this will serve as useful } \\
\text { feedback for facilitators, and identify anything about the session that should be changed for } \\
\text { the future) } \\
\text { Thank participants for ioining }\end{array}$ \\
\hline End debrief & Thank them for participating! \\
\hline
\end{tabular}

References:

- Podovei M, Bernstein K, George R, Habib A, Kacmar R, Bateman B, Landau R. Interim Considerations for Obstetric Anesthesia Care related to COVID19. Accessed 3/17/20 at: https://soap.org/wpcontent/uploads/2020/03/SOAP COVID-19 Obstetric Anesthesia Care 031620-2.pdf.

- Clinton E. COVID-19 simulation script. Department of Obstetrics \& Gynecology, Massachusetts General Hospital, Boston, MA, USA

- Torbenson V. OB Simulation Emergency Drill 2020. Department of Obstetrics \& Gynecology, Mayo Clinic, Rochester, MN, USA

- Chan A, Lau V, Wong H. Covid-19 Sample Scenario Script for Airway Management in OT. Department of Anaesthesia and Intensive Care, Prince of Wales Hospital, Hong Kong.

- ACOG Committee Opinion 644. The Apgar Score. Accessed 3/17/20 at: https://www.acog.org/Clinical-Guidance-andPublications/Committee-Opinions/Committee-on-Obstetric-Practice/The-Apgar-Score?IsMobileSet=false.

- World Health Organization. Infection prevention and control during health care when novel coronavirus (nCoV) infection is suspected. Accessed 3/17/20 at: https://www.who.int/publications-detail/infection-prevention-andcontrol-during-health-care-when-novel-coronavirus-(ncov)-infection-is-suspected-20200125.

- Zhou F, Yu T, Du R, Fan G, Liu Y, Liu Z, et al. Clinical course and risk factors for mortality of adult inpatients with COVID-19 in Wuhan, China: a retrospective cohort study. The Lancet. 3/15/20 at:

https://www.thelancet.com/journals/lancet/article/PIIS0140-6736(20)30566-3/fulltext.

- Fauci AS, Lane C, Redfield RR. Covid-19-Navigating the Uncharted. NEJM. Accessed 3/15/20 at: https://www.nejm.org/doi/full/10.1056/NEJMe2002387

Fig. 1. (continued).

obstetric patient with suspected COVID-19 in labor requiring cesarean delivery; and (4) an obstetric patient with suspected COVID-19 requiring intensive care unit transfer due to worsening respiratory symptoms. ${ }^{44}$ SOAP provided a scripted simulation scenario designed to guide teams through meeting a parturient with suspected COVID-19 team in triage, transport to a labor room and placement of a labor epidural, emergency cesarean delivery, induction, and recovery from a general anesthetic (Fig. 1). ${ }^{18}$ Simulation has been proposed as a mechanism for addressing novel scenarios brought about the pandemic, such as donning and doffing of PPE, transport of infected obstetric patients, management of a second obstetric emergency when the team currently is caring for an obstetric patient, approaches to the delay of an emergency cesarean delivery due to infection prevention and control measures, and communication with patients or families about visitation policies impacted by infection prevention and control measures. ${ }^{45}$ Simulation scenarios also have been described to include not only multidisciplinary care of the obstetric patient but also neonatal care based on variable maternal COVID-19 status and symptomatology and gestational age at the time of delivery. ${ }^{46,47}$

The COVID-19 pandemic required major changes to not only workflow but also patient care areas in efforts to maximize infection prevention and control while providing patient care. Simulation served as the means for testing and revising these changes in real time throughout the world. Lie and colleagues ${ }^{48}$ reported the use of plan-do-study-act cycles incorporating simulation to identify process threats, infection control threats, and equipment or PPE issues and then modified their COVID-19 patient care workflow based on their findings. Wong and colleagues ${ }^{49}$ utilized 
simulated drills to test the feasibility of changes to their operating room setup and workflow. Findings based on these drills led to the designation of an operating room coordinator to ensure adherence to the protocol they had developed. Muhsen and colleagues ${ }^{50}$ describe major changes made to their maternity ward floor plan, introduction of radio communications, and increases in staffing following simulation training sessions in preparation for care of COVID-19 infected obstetric patients. Other groups describe the use of simulation as part of the development of anesthetic care-specific checklists and protocols, including labor analgesia, neuraxial anesthesia for cesarean delivery, conversion of a labor epidural to cesarean delivery, and general anesthesia for the obstetric patient. ${ }^{51}$ One group incorporated actual obstetric patients into live simulation drills by providing their care as if they were patients infected with COVID-19, to test preliminary protocols designed for care of obstetric patients infected with COVID-19, and cited positive reactions from the patients involved. ${ }^{52}$

\section{THE FUTURE OF SIMULATION IN OBSTETRIC ANESTHESIOLOGY}

Although the COVID-19 pandemic served as a crisis that showcased the value simulation brings to education, training, and preparedness in the field of obstetric anesthesiology, the limits placed on human interaction due to social distancing requirements accelerated the shift in learning and communicating to the virtual environment. The seeds of this evolution in the world of simulation existed prior to the pandemic, and recent literature provides a rough sketch of the world of simulation that may come into existence in the future. A recent review of alternatives to high-fidelity simulation by Delisle and colleagues ${ }^{53}$ describes many of the modalities that do not require inperson training with partial task trainers or high-fidelity manikin-based simulation. Telesimulation allows for remote observation of a simulation scenario with live remote debriefing extending the geographic reach of a single simulation session for learners separated by vast distances. Screen-based simulation removes the need for a live instructor through the use automated facilitation and feedback mechanisms. Gamebased simulation, much like screen-based simulation, removes the requirement of a live instructor but also incorporates motivational aspects that exist in popular single-player or multiplayer videogames and can incorporate both technical and nontechnical skills. Improvements in virtual reality technology will allow game-based simulation increasingly to approach or surpass the fidelity of existing manikin-based simulation technology. Benda and colleagues ${ }^{54}$ utilized an obstetric scenario to compare the educational effectiveness of serious game training to high-fidelity manikin-based training. Groups randomized to manikin-based or serious gamebased training prior to an assessment of performance in a high-fidelity manikin-based simulation scenario showed no difference in overall performance.

\section{SUMMARY}

Although the role of simulation in training and assessment of individuals, multidisciplinary teams, and the work environment in obstetric anesthesiology continued at the end of the second decade of the twenty-first century, the COVID-19 pandemic provided the ideal circumstances to reveal the unparalleled value simulation brings to training and preparation for emergencies, both locally and globally. Ironically, this turbulent period of pandemic health care, in which high-fidelity, team-based simulation has shone so brightly, likely will accelerate the transition toward alternative modes of simulation-based training and assessment through the increased use and capability of virtual platforms and screen-based learning environments. 


\section{CLINICS CARE POINTS}

- Simulation in obstetrical anesthesia should continue to be utilized to teach and to assess the competencies of the individual, the group and the institution at large.

- The COVID-19 pandemic showcased the ability of simulation in obstetrical anesthesiology to evolve and to address new and unprecedented emergencies within the obstetric unit.

- Simulation in obstetrical anesthesia will continue to evolve as technology advances and as the world encounters new medical challenges.

\section{DISCLOSURE}

The authors have nothing to disclose.

\section{REFERENCES}

1. Pratt SD. Simulation in obstetric anesthesia. Anesth Analg 2012;114(1):186-90.

2. Pratt SD. Recent trends in simulation for obstetric anesthesia. Curr Opin Anaesthesiol 2012;25(3):271-6.

3. Wenk M, Pöpping DM. Simulation for anesthesia in obstetrics. Best Pract Res Clin Anaesthesiol 2015;29(1):81-6.

4. Schornack LA, Baysinger CL, Pian-Smith MCM. Recent advances of simulation in obstetric anesthesia. Curr Opin Anaesthesiol 2017;30(6):723-9.

5. Clinton E, Minehart RD. Simulation in obstetrics. In: Mahoney B, Minehart RD, Pian-Smith MCM, editors. Comprehensive healthcare simulation: anesthesiology. Switzerland: Springer International Publishing; 2020. p. 221-9.

6. Marynen F, Van Gerven E, Van de Velde M. Simulation in obstetric anesthesia: an update. Curr Opin Anaesthesiol 2020;33(3):272-6.

7. Leighton BL. A greengrocer's model of the epidural space. Anesthesiology 1989. https://doi.org/10.1097/00000542-198902000-00038.

8. Vaughan N, Dubey VN, Wee MYK, et al. A review of epidural simulators: where are we today? Med Eng Phys 2013;35(9):1235-50.

9. Brazil AL, Conci A, Clua E, et al. Haptic forces and gamification on epidural anesthesia skill gain. Entertain Comput 2018;25:1-13.

10. Moo-Young J, Weber TM, Kapralos B, et al. Development of unity simulator for epidural insertion training for replacing current lumbar puncture simulators. Cureus 2021;13(2):e13409.

11. A. L. Brazil, A. Conci, E. Clua, et al. "Force modeling and gamification for Epidural Anesthesia training." In: IEEE international Conference on serious games and applications for health (SeGAH). IEEE; 2016. p. 1-8.

12. Capogna E, Salvi F, Vecchio A Del, et al. Changes in gaze behavior during the learning of the epidural technique with a simulator in anesthesia novices. Open J Anesthesiol 2020;10(11):361-70.

13. Ortner CM, Richebé $P$, Bollag LA, et al. Repeated simulation-based training for performing general anesthesia for emergency cesarean delivery: long-term retention and recurring mistakes. Int J Obstet Anesth 2014;23(4):341-7.

14. Scavone BM, Sproviero MT, McCarthy RJ, et al. Development of an objective scoring system for measurement of resident performance on the human patient simulator. Anesthesiology 2006. https://doi.org/10.1097/00000542-20060800000008. 
15. Eason M, Olsen ME. High spinal in an obstetric patient: a simulated emergency. Simul Healthc 2009;4(3):179-83.

16. Lee A, Sheen JJ, Richards S. Intrapartum maternal cardiac arrest: a simulation case for multidisciplinary providers. Mededportal J Teach Learn Resour 2018; 14:10768.

17. Obr C, Mueller A. Diabetic ketoacidosis in the obstetric population: a simulation scenario for anesthesia providers. MedEdPORTAL 2016;12(1):1-5.

18. Minehart R, Abir G, Arendt K, et al. COVID19 labor to Cesarean delivery: case flow and facilitator's guide. Available at: https://soap.memberclicks.net/covid19-toolkit. Accessed May 24, 2021.

19. Sree Kumar EJ, Purva M, Chander MS, et al. Impact of repeated simulation on learning curve characteristics of residents exposed to rare life threatening situations. BMJ Simul Technol Enhanc Learn 2020;6(6):351-5.

20. Kariya N, Kawasaki Y, Okutani $\mathrm{H}$, et al. Effects of simulation study of high neuraxial block during epidural analgesia for labor pain on pre/posttest evaluation in junior clinical trainees. Anesthesiol Pain Med 2020;10(1):3-7.

21. Teixeira JARM, Alves C, Martins C, et al. General anesthesia for emergency cesarean delivery: simulation-based evaluation of residents. Braz J Anesthesiol 2021. https://doi.org/10.1016/j.bjane.2021.02.059.

22. Raemer DB, Kolbe M, Minehart RD, et al. Improving anesthesiologists' ability to speak up in the operating room: a randomized controlled experiment of a simulation-based intervention and a qualitative analysis of hurdles and enablers. Acad Med 2016;91(4):530-9.

23. Szmulewicz C, Rouby P, Boyer C, et al. Communication of bad news in relation with surgery or anesthesia: an interdisciplinary simulation training program. J Gynecol Obstet Hum Reprod 2021;50(7):102062.

24. Okrainec A, Henao O, Azzie G. Telesimulation: an effective method for teaching the fundamentals of laparoscopic surgery in resource-restricted countries. Surg Endosc 2010;24(2):417-22.

25. Sorensen JL, Van der Vleuten C, Rosthoj S, et al. Simulation-based multiprofessional obstetric anesthesia training conducted in situ versus off-site leads to similar individual and team outcomes: a randomized educational trial. BMJ Open 2015;5(10):e008344-e008344.

26. Lim G, Krohner RG, Metro DG, et al. Low-fidelity haptic simulation versus mental imagery training for epidural anesthesia technical achievement in novice anesthesiology residents: a randomized comparative study. Anesth Analg 2016; 122(5):1516-23.

27. Kiwalabye I, Cronjé L, Schoeman S, et al. A simulation-based study evaluating the preparedness of interns' post-anaesthesia rotation in managing a failed obstetric intubation scenario: Is our training good enough? South Afr Med J 2021; 111(3):265-70.

28. Dabbagh A, Elyassi H, Sabouri AS, et al. The role of integrative educational intervention package (Monthly ITE, mentoring, mocked OSCE) in improving successfulness for anesthesiology residents in the national board exam. Anesthesiol Pain Med 2020;10(2):e98566.

29. Calvert KL, McGurgan PM, Debenham EM, et al. Emergency obstetric simulation training: how do we know where we are going, if we don't know where we have been? Aust N Z J Obstet Gynaecol 2013;53(6):509-16.

30. Arriaga AF, Gawande AA, Raemer DB, et al. Pilot testing of a model for insurerdriven, large-scale multicenter simulation training for operating room teams. Ann Surg 2014;259(3):403-10. 
31. Bogne kamdem valery, Daelemans C, Englert Y, Morin F, et al. Using simulation team training with human's factors components in obstetrics to improve patient outcome: a review of the literature. Eur J Obstet Gynecol Reprod Biol 2021; 260:159-65.

32. Lutgendorf MA, Spalding C, Drake E, et al. Multidisciplinary in situ simulationbased training as a postpartum hemorrhage quality improvement project. Mil Med 2017;182(3):e1762-6.

33. Austin N, Goldhaber-Fiebert S, Daniels K, et al. Building comprehensive strategies for obstetric safety: simulation drills and communication. Anesth Analg 2016;123(5):1181-90.

34. Dillon SJ, Kleinmann W, Seasely A, et al. How personality affects teamwork: a study in multidisciplinary obstetrical simulation. Am J Obstet Gynecol 2021; 3(2): 100303.

35. Capogna E, Capogna G, Raccis D, et al. Eye tracking metrics and leader's behavioral performance during a post-partum hemorrhage high-fidelity simulated scenario. Adv Simul 2021;6(1):1-12.

36. Cheloufi M, Picard J, Hoffmann P, et al. How to agree on what is fundamental to optimal teamwork performance in a situation of postpartum hemorrhage? A multidisciplinary Delphi French study to develop the Obstetric Team Performance Assessment Scale (OTPA Scale). Eur J Obstet Gynecol Reprod Biol 2021; 256:6-16.

37. Homcha BE, Mets EJ, Goldenberg MDF, et al. Development and assessment of pictorial guide for improved accuracy of visual blood loss estimation in cesarean delivery. Simul Healthc 2017;12(5):314-8.

38. Piekarski F, Gerdessen L, Schmitt E, et al. Quantification of intraoperative blood loss in a simulated scenario using a novel device. Shock 2020;55(6): 759-65.

39. Taylor J, Chau A, Gunka V, et al. The incidence of dry chlorhexidine gluconate transfer from skin to surgical gloves: a simulation and in vitro study. Int J Obstet Anesth 2021;45:111-4.

40. Mhyre J, Ward N, Whited TM, et al. Randomized controlled simulation trial to compare transfer procedures for emergency cesarean. J Obstet Gynecol Neonatal Nurs 2020;49(3):272-82.

41. Alexander LA, Newton MW, McEvoy KG, et al. Development and pilot testing of a context-relevant safe anesthesia checklist for cesarean delivery in East Africa. Anesth Analg 2019;128(5):993-8.

42. Gallardo AR, Meneghetti G, Franc JM, et al. Comparing resource management skills in a high- versus low-resource simulation scenario: a pilot study. Prehosp Disaster Med 2020;35(1):83-7.

43. Lee JSE, Chan JJI, Ithnin F, et al. Resilience of the restructured obstetric anaesthesia training programme during the COVID-19 outbreak in Singapore. Int J Obstet Anesth 2020;43:89-90.

44. Eubanks A, Thomson B, Marko E, et al. Obstetric simulation for a pandemic. Semin Perinatol 2020;44(6):151294.

45. Kiely DJ, Posner GD, Sansregret A. Health Care team training and simulationbased education in obstetrics during the COVID-19 pandemic. J Obstet Gynaecol Can 2020;42(8):1017-20.

46. Rastogi S. Simulations of deliveries of SARS-CoV-2 positive pregnant women and their newborn babies: plan to implement a complex and ever-changing protocol. Am J Perinatol 2020;37(10):1061-5. 
47. Benlolo S, Nensi A, Campbell DM, et al. The use of in situ simulation to enhance COVID-19 pandemic preparedness in obstetrics. Cureus 2021;13(1):1-6.

48. Lie SA, Wong LT, Chee M, et al. Process-oriented in situ simulation is a valuable tool to rapidly ensure operating room preparedness for COVID-19 outbreak. Simul Healthc 2020;15(4):225-33.

49. Wong J, Goh QY, Tan Z, et al. Preparing for a COVID-19 pandemic: a review of operating room outbreak response measures in a large tertiary hospital in Singapore. Can J Anesth 2020;67(6):732-45.

50. Muhsen WS, Marshall-Roberts R. Simulation-guided preparations for the management of suspected or confirmed COVID-19 cases in the obstetric emergency theater. J Matern Neonatal Med 2020;0(0):1-4.

51. Li Y, Ciampa EJ, Zucco L, et al. Adaptation of an obstetric anesthesia service for the severe acute respiratory syndrome coronavirus-2 pandemic: description of checklists, workflows, and development tools. Anesth Analg 2021; 132(1):31-7.

52. Cegielski D, Darling C, Noor C, et al. Patients as partners in readiness for COVID19: using 'live simulation' to implement infection prevention and control procedures in the maternity operating theatre. Anaesth Rep 2020;8(2):191-5.

53. Delisle M, Hannenberg AA. Alternatives to high-fidelity simulation. Anesthesiol Clin 2020;38(4):761-73.

54. Benda NC, Kellogg KM, Hoffman DJ, et al. Lessons learned from an evaluation of serious gaming as an alternative to mannequin-based simulation technology: Randomized controlled trial. JMIR Serious Games 2020;8(3):1-12. 